\title{
The dramaturg's gaze as a gateway to relevant, responsive, and relational pedagogical practice
}

Rose Martin (PhD, Dance Studies)

Norwegian University of Science and Technology (NTNU), Norway

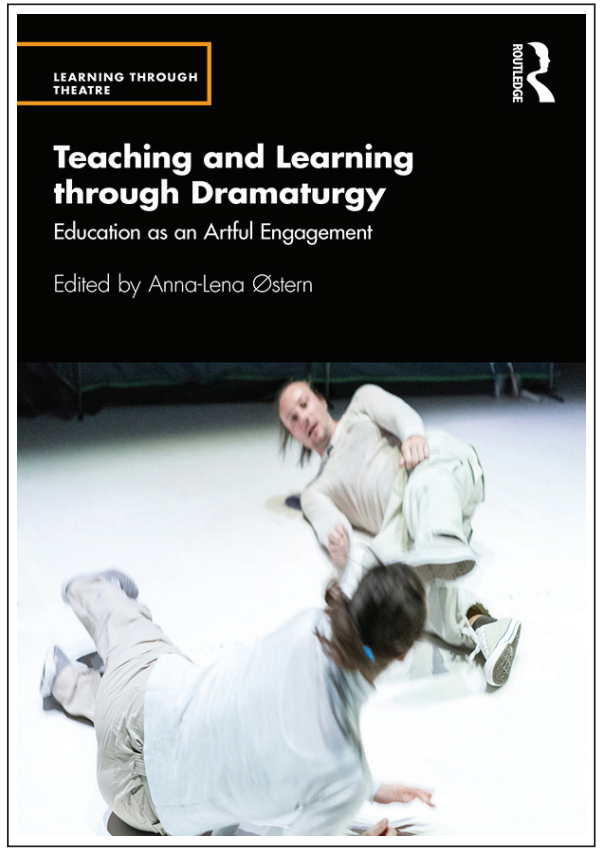

Østern, A.-L. (Ed.). (2021). Teaching and learning through dramaturgy: Education as an artful engagement. Routledge. 156 pages. ISBN: 9780367549084.

Within the current world we live in dramaturgical thinking is vital. Teaching and Learning through Dramaturgy: Education as an Artful Engagement, edited by Anna-Lena Østern, illustrates not only how dramaturgy is significant in teaching and learning, but it allows an echo of what dramaturgy can offer us as humans in a world faced with unparalleled uncertainty and challenges.

The carefully crafted publication draws together ten chapters from contributors who offer unique voices exploring and engaging with notions of dramaturgy in 


\section{R. Martin}

education in diverse ways. Opening with a foreword from John O'Toole, the stage is set for an "imaginative leap" (p. 8) into the text. With authors coming from drama/ theatre, physical education, dance, education, and music - with many working across and through these various disciplines - a depth to the topic emerges with force right from the opening chapter, 'Dramaturgical action repertoire - openings, breaches, encounters'. The notion of "the teacher's action repertoire" (p. 16) is raised, and it becomes evident that this book should indeed be viewed as part of that repertoire for teachers in a variety of contexts, with a variety of experiences and backgrounds.

The chapters journey through topics such as the world of the dramaturg, dramaturgical models, theatre addressing 'big' questions of contemporary times, and the physicality of a teacher's practice. They navigate themes such as ethics and the dramaturgy of oral presentation, allowances of dramaturgical thinking in outdoor education, creating atmosphere in the learning space, relational and nomadic dramaturgies. The ten chapters dip and dive across a variety of theoretical terrains pedagogical, performative, posthuman, embodied, and design. Methodologically the chapters navigate a range of practice-based approaches, narrative engagements, and embodied and performative strategies. Photos, QR-codes, figures, sketches, collages, montages and tables offer visual elements to the chapters. The richness of how the book is formatted, along with the weaving of theory and methods throughout, allows the reader to have a feeling of being 'in' the dramaturgical encounters and moments that the authors seek to address within their writings.

Teaching and Learning through Dramaturgy: Education as an Artful Engagement is a book that delivers tangible examples of practice woven with theory, refined and considered in a way that is both highly accessible and relevant, but also deeply intellectual with the highest academic rigor. For those working in the broad field of education or any spaces where teaching takes place, this text is not only of relevance, but it offers a way to think about teaching and learning with depth, care and practice. As Anna-Lena Østern states at the opening of chapter 2, "A dramaturg poses one main question: What story do I want to tell?" (p. 25). This question is extraordinarily important for consideration as educators - what story are we telling? What story do we want to tell? What stories are heard? And, what stories are silenced? Østern goes on to note, "theatre must be of significance, have something at heart" (p. 25). I would argue that similarly education must also be of significance and have heart. What this book offers us is strategies, thoughts, practices and considerations to allow stories to leap forward with power, and in turn allowing space for the feeling, the heart, to come forth. 